\title{
REDEVELOPMENT OF INDUSTRIAL ZONES AS A TOOL OF CITY DEVELOPMENT
}

\section{Pandas Anastasiia ${ }^{1}$}

DOI: https://doi.org/10.30525/978-9934-571-78-7_13

Abstract. During the last decade, deindustrialization of large cities has become widely publicized. Due to the reduction in production, large degraded industrial areas with unused buildings, warehouse premises and associated infrastructure appeared. The spatial structure of such zones requires a consistent transformation based on multi-purpose analysis. In connection with this, there is a need for work on the reconstruction of industrial zones, their adaptation to modern conditions of city functioning and sustainable development. Redevelopment of the industrial zone-one of the most popular worldwide transformation tools of urban space. Analyzing world experience, redevelopment gives a significant impetus to the rational and sustainable development of the city. This is the creation of a new space for the emergence of real estate, business, space for communications, the development of creative areas. The purpose of studying the substantiation of theoretical and practical bases of redevelopment, as well as actualization, use of world practices of redevelopment; development of the concept of redevelopment of the industrial zone; consideration of problem issues, obstacles and motivational levers in realization of projects of redevelopment of industrial zones. Methodology of research. Empirical (measurement and comparison) and theoretical methods (study and synthesis, analysis and synthesis).

\section{Introduction}

Environmentalization of urban space - a process aimed at preserving and improving the quality of the natural environment of urban space, through managerial, economic, technical and other decisions, which allow to increase the efficiency of resources used (including land) and reduce the man-made load on the environment . One of the important circumstances

\footnotetext{
${ }^{1}$ Candidate of Economic Sciences, Assistant Professor at Department of Economy and Entrepreneurship, Odessa State Academy of Civil Engineering and Architecture, Ukraine 


\section{Pandas Anastasiia}

that impedes the implementation of environmentalization is the expansion of the boundaries of cities, and as a consequence, industrial zones are deeply involved in the urban structure of the city. Industrial production, located on the outskirts, appeared in the central regions, which entails a lot of environmental, economic, urban and social problems. There are all signs of irrational development of urban space.

The tool for solving this problem may be the process of redevelopment of industrial zones.

Redevelopment is a good practice around the world. The redeveloped production areas become new points of attraction in cities, using to create multifunctional clusters that combine various objects of real estate, recreational areas, research and innovation centers, cultural and educational objects, etc. Redevelopment has a multi-faceted effect: improving the architectural and planning development of the city, the emergence of new land resources, real estate objects, workplaces, transformation and development of the transport network, reducing pendular migration, addressing environmental problems. The redesign of industrial zones has the maximum effect and expediency only due to the multifunctional use of the territory with a systematic and systematic transformation.

From the point of view of the state, redevelopment is a set of measures aimed, ultimately, to increase the cost and improve the liquidity of the land and its improvements. From the point of view of commercial structures, redevelopment can generate profits for the creation of added value by changing the functional purpose or modernization of buildings.

The tasks of organizations involved in redevelopment can be characterized as follows: assessment and selection of the object or area of redevelopment, justification and organization of chain links: the right holder - authorities - the bank - the designer - the builder - the tenant / buyer. At the same time, specialists of such organizations should have the necessary knowledge in the field of expertise of land, real estate, valuation, brokerage and management.

\section{Theoretical and practical aspects}

Redevelopment(from theEnglishre-and development «re-development») is the process of re-profileing the property under a new direction [1, p. 15].

In the Western economy, redevelopment is called entrepreneurial activity associated with the transformation of the property to another, a new 


\section{Chapter «Economic sciences»}

object, with another functional purpose, resulting in the cost of the object increases. In domestic practice, this direction of entrepreneurial activity is called the development of territories.

Redevelopment has the following classification:

Full redevelopment - a complete redevelopment of objects and territories, starting with the change of the target destination of the plot.

Partial redevelopment - the redevelopment of urban areas and in part of the objects, with the renovation of existing transport solutions and engineering networks.

Surface redevelopment - does not imply serious changes to existing objects, redevelopment subject to individual objects of property complex [2, p. 100].

Improvement of the functional qualities of an object of real estate, which leads to an increase in its value, can be realized through various city-building decisions, depending on many factors, including its material and moral depreciation, historical and cultural or urban development value, functional variability, etc. The main processes in which objects can be transformed are: reconstruction, restoration with adaptation to new use, new construction after demolition.

Key prerequisites for initiating the process of redevelopment of production areas are de-industrialization and the loss of the initial functions of industrial facilities. Redevelopment of territories, provides for a complex of actions in various spheres: economic, urban, ecological, social, industrial, etc. At the same time, the process of redevelopment integrates a variety of processes of changing the technical and economic characteristics of objects, their functional purpose, architectural and spatial organization and socio-cultural significance of territories. Regarding production areas, redevelopment is always a unique task, which is solved by modeling the processes of modern use of industrial objects on the basis of internal (density of development, intensity of use of territory, volumetric - spatial, functional constructive and architectural and stylistic characteristics of objects) and external environmental factors (transport and communication of the territory, pedestrian accessibility and permeability, social activity, sociocultural significance of the territory) are predicted Nami of the future transformation of territory [3, p. 15].

In professional terminology, the definition of redevelopment is detailed by special terms, each of which corresponds to a specific method of improving the productivity of the land: 


\section{Pandas Anastasiia}

Reprocessing involves changing the functional purpose, the permitted use, the legal status of the object and further use it in a new quality.

Reconstruction (from re- and lat.sonstructio - rebuilding) - carrying out complex construction and finishing works in order to qualitatively change the technical and economic indicators of the building. The primary objective of the reconstruction is the restoration of the functional qualities of the building, which is achieved by carrying out the following works: full or partial reorganization of the object with a change in overall dimensions and technical characteristics; carrying out additional construction works (add-ons, extensions); reconstruction or full replacement of all engineering communications; reinforcement of bearing structures. In the process of reconstruction of a building from the original elements, usually only bearing structures - walls, ceilings, stairs are preserved [3, p. 16].

Regeneration (from the Latin regeneratio - revival) - in relation to the historical and urban environment-actions aimed at the restoration, reproduction, filling of partially or completely lost elements and / or characteristics of the historical and urban development and / or the natural environment.

Ingredients of regeneration:

Revitalization, rehabilitation (from Latin rehabilitate, recovery, from Latin re-recovery and vita-life, literally: returning life) - increasing functional significance by restoring lost or developing new non-destructive complex of social functions [4, p. 49].

Renovation (from lat. renovation - update - restoration) - involves the process of improving the functionality of the object while maintaining its design features, while keeping in mind the innovative upgrade. In industrial construction is considered, as the technical and economic substitution process is left out of production, as a result of the physical and moral depreciation of equipment, a tool for new fixed assets at the expense of the depreciation fund, as one of the processes of complex reconstruction of industrial facilities. Regarding territories, the renovation involves changing its functionality to more innovative forms, for example, the abandonment of resource-intensive industries in favor of post-industrial sectors of the economy. Renovation may include the complete demolition of the object in order to free the site for a new construction. In this situation, the historical and social significance of the object plays an important role.

Based on the above scheme (Figure 1), One can draw conclusions on the main tasks facing the company engaged in redevelopment: 


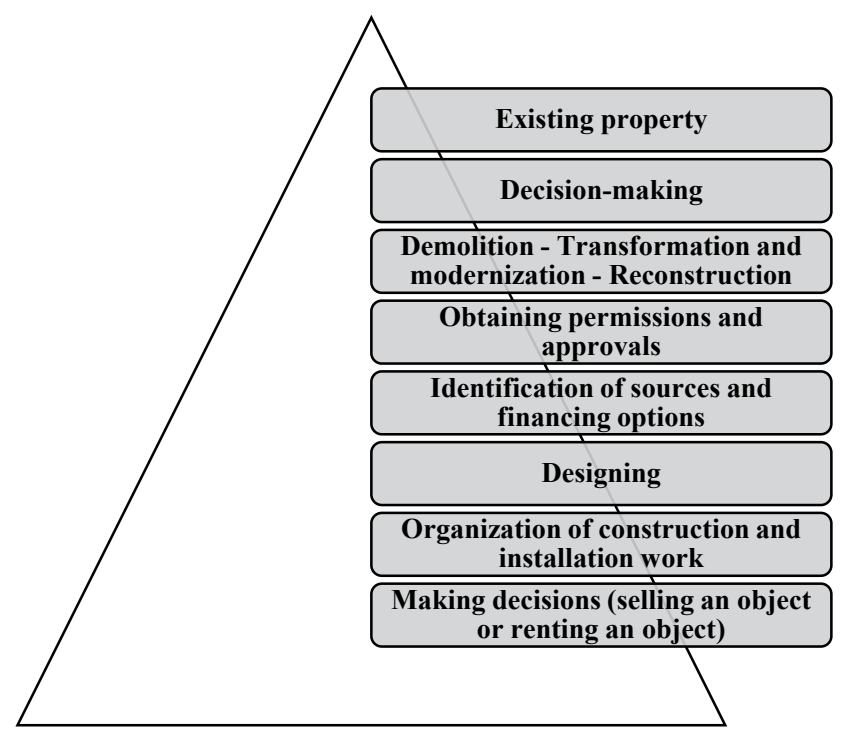

Figure 1. Contents of the redevelopment process

Select a redevelopment object. Finding a potentially lucrative facility essentially means assessing the future demand for alternative uses of existing real estate and calculating construction costs for such use. Of all the options, a project should be selected, which, under the existing restrictions (for example, financial), gives the maximum net income. As a rule, the initial assessment involves detailed studies of physical characteristics of the resource, the availability of appropriate building capabilities, social infrastructure, environmental characteristics. On the basis of the performed research, a preliminary design and evaluation of the redevelopment project is carried out.

Purchase an item for redevelopment. Acquisition of property rights to real estate can take a considerable time, up to several years. This is due to the monopoly of individual interests (if the rights to real estate belong to different owners) who are able to use the uniqueness of their position. During this time, demand or construction costs may change. Therefore, the redealer must provide additional costs beyond the normal cost of purchasing and construction. Such additional costs include the cost of ownership of land and its improvements in anticipation of the moment of profitability of 


\section{Pandas Anastasiia}

redevelopment and expenses during the period of redevelopment-payment of specialists, interest payments.

Obtaining permissions and approvals. The best is the case when all agreements are made prior to the acquisition of the site, if permitted by local law. This reduces the uncertainty of economic forecasts for density of construction, restrictions and mandatory deductions. Otherwise, obtaining approvals indefinitely increases the period of redevelopment, which leads to additional costs of financing.

Usually, the process of reconciling building documentation and obtaining a building permit is carried out by specialized organizations. These are either consulting companies that are building organizations that have a great deal of practice in this kind of activity and have established business relationships with the authorities involved in this process.

Organization of financing. To cover all expenses of the redevelopment, short-term financing should be organized for the period until the completion of construction (on average 1-3 years). As the risk associated with the construction period is greater than the risk during the operation of the finished facility, the interest rates for short-term financing are rather high, and the redeveloper has a strong incentive to reduce the construction time. Upon completion of the redevelopment, the finished object is either sold or remains at the disposal of the redeveloper. In the second case, the redeveloper must arrange long-term financing (usually for 5-10 years). In some cases, long-term financing is issued, starting from the moment of redevelopment. Funding can be organized on the basis of equity, or with the attraction of borrowed capital, which can be economically more efficient.

Organization of design and construction. As a rule, the redeveloper, as a rule, involves specialized organizations, or uses own units, to perform design and construction and installation work. Constant monitoring at the design and construction stage allows the retailer to reduce some of the risks of the construction period.

Lease or sale of a finished object. Redevelopment is considered completed at the time of sale or sale of the finished object, or, if the redealer intends to leave it at the disposal, at the time of full lease. In the latter case, the object of redevelopment becomes an object of long-term investment.

In the period of the formation of the professional market of redevelopment of real estate the important issue is the structure of the participants of the project of redevelopment, which will ensure the successful outcome of the 


\section{Chapter «Economic sciences»}

project. Schematically, the interaction of participants in the redevelopment project can be displayed as follows:

\section{The essence of redevelopment of industrial zones}

The use of the territories of the former industrial zones, as well as the search for new approaches to renovation today, is one of the actual world trends that can breathe new life into the architectural environment of cities [4, p. 89].

The industrial zone is a functional, specialized part of the city's territory, which includes objects of material production, utilities, industrial infrastructure, science, scientific services, personnel training, and other objects of the nonproductive sphere, serving material and non-material production [5].

One of the significant shortcomings of the industrial industrial zones of cities is the groundlessness of their planning structure, its accident, the lack of a single plan in the architectural and spatial organization

Improvement of the planning structure, its transformation is a long and complex process, which in each industrial zone has specific features [6].

The planning structure of the city should be divided into three types of industrial zones, as shown in Table 1.

One of the options for using industrial zones is the complete demolition of existing facilities and the construction of new complexes. Such a method may be economically disadvantageous as the cost of dismantling and clearing the territories increases.

Redirection (renovation) allows you to use up to $90 \%$ of existing buildings, which is more economical new construction. In this case, in many cases, industrial buildings are within the boundaries of historical development or are architectural monuments themselves [7, p. 9].

From a functional point of view, there are three fundamentally different directions for the transformation of industrial areas:

1) Preservation of industrial function:

- memorial way - restoration of the building, preservation of its architectural-historical appearance (for monuments of industrial architecture);

- improvement - introduction of new production technologies in the existing volume of the building and reconstruction of the object;

2) Partial refocusing:

- reconstruction of the planning structure, the main principle of which is the isolation and preservation of the most sustainable planning characteristics; 
Table 1

Types of industrial zones and their influence on reconstruction measures

\begin{tabular}{|c|l|l|}
\hline $\begin{array}{c}\text { Type of } \\
\text { industrial } \\
\text { zone }\end{array}$ & Location & \multicolumn{1}{c|}{$\begin{array}{c}\text { Features of the zone and their impact } \\
\text { on the reconstruction activities }\end{array}$} \\
\hline $\begin{array}{c}\text { Industrial zone } \\
1 \text { level }\end{array}$ & $\begin{array}{l}\text { Historically formed } \\
\text { city center }\end{array}$ & $\begin{array}{l}\text { In this case, it is necessary to take into account: } \\
\text { the close location of the places of residence, } \\
\text { the existing system of social and cultural } \\
\text { services for the population, the existing system } \\
\text { of engineering provision of the industrial and } \\
\text { residential zone, the historical and architectural } \\
\text { and artistic value of industrial development } \\
\text { and its environment, the complexity of } \\
\text { changing the planning structure of the } \\
\text { industrial area and its inextricable connection } \\
\text { with the local areas. }\end{array}$ \\
\hline $\begin{array}{c}\text { Industrial zone } \\
2 \text { level }\end{array}$ & $\begin{array}{l}\text { The peripheral } \\
\text { part of the city } \\
\text { may be adjacent } \\
\text { to residential } \\
\text { formations }\end{array}$ & $\begin{array}{l}\text { In this case, it is necessary to take into } \\
\text { account the increase in the share: high-speed } \\
\text { and individual transport, the relative planning } \\
\text { autonomy of the formed industrial districts. }\end{array}$ \\
\hline $\begin{array}{c}\text { Industrial zone } \\
3 \text { level }\end{array}$ & $\begin{array}{l}\text { Located in the } \\
\text { peripheral part of } \\
\text { the city at a distance } \\
\text { from the residential } \\
\text { building }\end{array}$ & $\begin{array}{l}\text { For such a zone characterized by significant } \\
\text { (500 hectares or more) size and industry } \\
\text { specialization. }\end{array}$ \\
\hline
\end{tabular}

- inclusion of new objects of urban significance in historical and industrial areas;

3) Full refocusing:

- re-functionalization of existing monuments of industrial heritage in accordance with criteria of socio-cultural demand and relevance (re-engineering of industrial objects for residential buildings, administrative and office centers, educational establishments, cultural and entertainment centers, hotels, trade enterprises, sports facilities);

- ecological rehabilitation of the territory through the reclamation of disturbed territories, the creation of new green spaces (parks, squares, alleys) [8, p. 89];

- complete demolition of the industrial object and the use of the territory for other purposes.

Among the many existing methods for reconstruction or refinancing of objects, we select a few basic ones that will allow us to adapt the industrial architecture to modern conditions. 


\section{Chapter «Economic sciences»}

- First, the «application» method involves creating a composition based on an existing design; This is a reconstruction of the facade, creating a «false-facade» (creating a composition of volumes and planes, different in color, texture, texture). This way involves working with the latest materials, creating a modern beautiful shell.

- The second - the method of «analogies» involves comparing the projected object with one or another of the properties of a figurative analog. The method is used just in case when it is necessary to give the object new qualities. It is more appropriate for industrial architecture to apply functional analogies: images, details, elements that speak not only about the functions of the building, but also about the specifics of the enterprise. Reception: functional - artistic use of engineering equipment delivered to the facade. As well as technical analogies: images that arose on the basis of a technical product, or conditional reflection on the facade of the technological process of the enterprise. Reception: real movement or artificially created effect of technology: illumination, etc.

- The third is «integration», that is, the insertion of additional elements and structures in existing building designs. Reception: the creation of new dominant or enhancement of the old, additions of volumes, communication spaces, changing the scale of the building [9, p. 85].

If we consider the relationship of industrial and residential volumes in the structure of urban development from the standpoint of composition, we can distinguish the following methods adaptation of industrial development to modern conditions:

- modification - the change of an object or its parts by proportions, form, position of parts, configuration;

- replacement - the introduction of new individual projections, forms, functions, structures, materials, etc.;

- eliminating or adding - reducing the number of forms, structures, functions or joining new ones that extend decision opportunities;

- combination - combinatorics of ideas, properties, functional components, elements of an object among themselves;

- inversion - a turning point, a consideration of a problem or a situation from the opposite.

Thus, there are several directions, methods and techniques of adaptation of the industrial heritage to the modern context of the city. And various architectural and compositional techniques allow to adapt and harmonize industrial objects to the structure of the actively developing modern city. 


\section{Pandas Anastasiia}

Classification of types of redevelopment can be based on the principle of coverage of the territory and the functional purpose of the object. Conditional redevelopment can be divided into territorial, that is, covers the territory of industrial zones entirely, and the object, when the transformed single point object integrates into the structure of the industrial zone, filling it with new functions (Figure 2) [10, p. 13].

The planning structure of industrial zones, which involves more rational use of the industrial area with an increase in its employment rate; detected territorial reserves, increase their degree of use due to increased density of development; streamlining of transport links and liquidation of lowimpact industrial enterprises; increase of architectural qualities of building, reduction of harmful influence of enterprises on the environment.

In a narrower sense, the redevelopment of industrial zones is the process of re-industrialization of industrial areas under a new direction. Redevelopment of industrial areas, as a rule, occurs in two types:

- when existing buildings in the industrial area are not demolished, but only reconstructed and transformed;

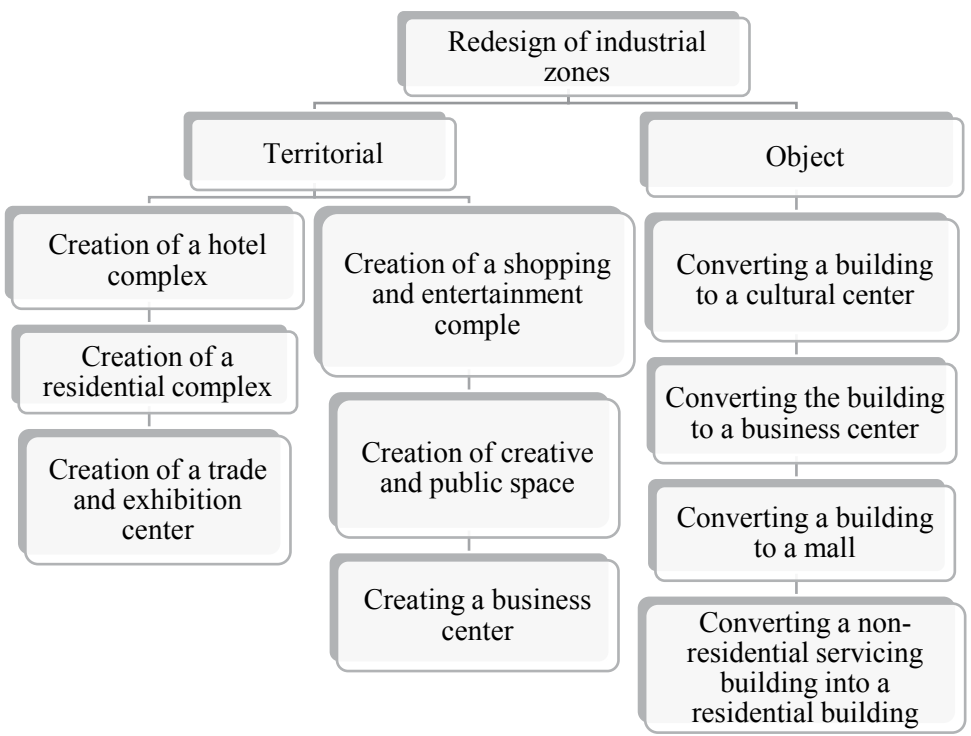

Figure 2. Classification of redevelopment formats for industrial zones 


\section{Chapter «Economic sciences»}

- when full or partial dismantling of buildings and structures in the industrial zone is carried out, and new real estate objects are being built in their place.

First of all, it should be noted that the process of redevelopment of industrial zones is much more complicated than the development of undeveloped territories. This is due to the fact that the owner of an object must take into account several key points:

1. Analysis of the best and most efficient use of the territory.

2. Kind of transformation works: demolition of existing buildings or reconstruction without demolition.

Most often, when the owners decide to reshape an object, without prior analysis of the location and optimal use, as a rule, this leads to the fact that the new object becomes unclaimed. Also, there is a misunderstanding that it is more profitable to demolish a building or reconstruct it. That is why it is important before the start of the redevelopment process to conduct an analysis to determine the best option for using the object and analyze the suitability of the existing design for the chosen direction.

The investor's interest in the redevelopment, first of all, is the possibility of building the object in a good location, in an area of sufficient size. For the city - is the revival of abandoned territories, the organization of new jobs, renovation and improvement of the city's portrait, replenishment of the revenue part of the local budget [11, p. 59].

Redevelopment of industrial real estate has significant advantages: high ceilings, huge windows, the possibility of free planning, electric and thermal power, convenience of access roads, parking lots and others [11, p. 60].

Historically, the reference point for the «redevelopment» is considered to be 1952, when the first projects appeared in America, which became the main driving force behind the revival of declining areas and irrationally used territories. During this period, there were companies that began to buy small outdated enterprises, demolish homes and build new economically attractive real estate objects in their place. One of the best examples of successful redevelopment in the world is the reconstruction of the former Docklands area of the port (London, UK), consider this project and others, the most successful ones.

Other European cities have long been practicing sealing and redefining the interior of the city, including industrial ones. So, in 1980, the former textile factory in the UK became the artistic center of «Salts Mill», which 


\section{Pandas Anastasiia}

is visited by about 100 thousand people each year. At the site of one of the largest shopping centers in Eastern Europe, «Manufaktura» in Poland, for many years was a textile factory.

\section{Key guidelines of the concept redevelopment of industrial areas}

Analysis of the world practice of redevelopment of industrial territories in connection with the cessation of production activity indicates the strengthening of the trends of the gentrification of the districts, the predominance of the choice of high-tech and creative industries, orientation to socially-demanded spheres: education, culture, and the creation of public spaces.

Analyzing the example of the transformation of the Berlin Tempelhof Airport, with an area of 380 hectares into a gigantic landscape park, where one functional assignment has replaced another, one can conclude that projects that are more successful are when multifunctional use comes in place of a single function.

According to modern realities, it would be appropriate to create multifunctional social and business zones of the city, which would be counted from:

1. High-tech and environmentally safe industries.

2. «Creative clusters» (art zones) - centers of contemporary art, for conducting various events (exhibitions, performances and festivals).

3. Business parks, business centers.

4. Cultural and entertainment centers.

5. Residential complexes.

6. Recreational zone.

The life cycle of the project for redevelopment of the industrial zone under the multifunctional social and business zone will consist of the following stages.

Stage 1. Analysis of the economic feasibility of the project. As part of the implementation of the phase, the analysis of expediency, economic efficiency and feasibility of the project options is analyzed, demand and supply in the market are analyzed, social value, profitability and liquidity are predicted. The basic assumptions and risks are formed. Evaluated investment and organizational capabilities, a business plan is being drawn up. As a result of the implementation of stage 1 a strategy for project implementation is formed. 


\section{Chapter «Economic sciences»}

Stage 2. Design. Immediately after the project strategy is formulated, a task for design and estimate documentation (DED) for reconstruction of buildings and conducting design and survey works can be completed. For performance of these works the third-party executor - the designer having the corresponding qualification certificate - is involved. The DED should reflect the investment plan of the project and comply with applicable legislation in urban planning and construction. To verify compliance with legislation and applicable norms, a DED examination is conducted by relevant independent experts. The conformity assessment of the DED to the investment plan is carried out by the customer. Obtaining the DED approved by the customer and the conclusion of the examination regarding the compliance of the DED with the applicable standards is the result of the implementation of the second phase.

Stage 3. Financing. The beginning of this stage is possible immediately after specifying in the DED the required amount of investment for the reconstruction. During this phase, additional sources of non-state financing are being sought - loan funds, attracting investors, finding future rental operators, etc. At the end of the stage, the amount of money needed to start the first stage of construction (reconstruction) must be received.

Stage 4. Construction. The fourth stage of the project can be started immediately after the examination of the DED and conducting permitting procedures at the start of preparatory work and construction. In the framework of the implementation of the stage, the facility for the reconstruction of garbage, preparatory work, reinforcement of structures and other construction work in accordance with the approved DED is being purified. As part of the stage, all finishing, design work, outdoor advertising is being installed, technological and engineering equipment and furniture are supplied and installed. The stage is completed by the acceptance of the complex in operation in accordance with the procedure provided for by law.

Stage 5. Sale and lease. Beginning of this stage, unlike the previous ones, can be started by the earlier - the better. Sale and lease of some components of a complex can find its future owner even at the stage of investment plan. Then, this host can act as the investor investor of the project and significantly save money in the future, when the price of finished real estate will inevitably increase. The main task of this stage is to ensure that the complex does not have unclaimed areas at the time of its delivery, and 


\section{Pandas Anastasiia}

the realization of these areas allowed to achieve the necessary profitability of the project. Consequently, the result of the fifth stage is the conclusion of lease or sale contracts for all areas.

Stage 6. Operation and management. The start of the stage is the moment of putting into operation. The tasks of the stage are to ensure maximum profitability from the exploitation of real estate, both for tenants and for the owners of the premises. The result of the stage is the achievement of planned payback and profitability of the project within the set time, as well as provision of the planned social value.

\section{The ecological and economic components concept of the industrial redevelopment}

However, special attention should be paid to the environmental component. Negative environmental heritage from abandoned industrial facilities is an obstacle to the development of this territory and existing buildings. The need for adequate, effective and durable use of this huge space on the market requires a major rehabilitation. First of all there is a danger from old pollution, it is necessary to evaluate:

1.Potential of danger from technological processes.

2. Potential of hazard from building materials.

3. Factory dumps of residual substances and waste products.

Objectives of the survey:

1.Define spatial distribution.

2. All data and documentary information is collected, systematized and documented.

3. Prepare documents for long-term use (entering into the register of contaminated areas).

4. Describe the objects of protection that are in potential danger, and the ways of spreading the dangers.

5. Determine the need for further action (urgent measures, sanation).

6. Prioritize for further action.

Stage 1. Inventory cadastre for pollution:

- systematic registration of all former industrial sites after use;

- inventory of hazardous substances;

- enterprise cadastre;

- systematic registration of all old deposits (landfills);

- pollution in groundwater/ surface waters. 


\section{Chapter «Economic sciences»}

Stage 2. Field studies:

- confirmation of suspicious moments of use;

- confirmation of suspicious moments of pollution.

Stage 3. Evaluation of research results:

- the type and volume of established pollution;

- impaired environment;

- evaluation of results on objects of protection;

- other disturbed environments / security objects;

- the type and extent of contamination of the site.

Stage 4. Assessment of the degree of danger:

- exceeding control values;

- formulation of the need for rehabilitation.

Stage 5. Adoption of the sanation decision:

- formulation of requirements for sanation;

- target value of sanation;

- the limits of sanation;

- making decisions about active / passive measures.

Stage 6. Approval of the sanation concept review of the sanation project:

- submission of the formulated rehabilitation goals;

- compliance with the legal basis.

The rehabilitation process describes for the contaminated site the possibility of performing sanitation on one appropriate sanitation or combination of methods, including all preparatory, accompanying and follow-up work, taking into account all infringed objects of protection, from the legal point of view of permissible use, and also all conditions on the site. Each sanation process must fulfill the sanction objectives, the provisions of the law, as well as the prescribed requirements for each individual case. On the basis of professional judgment, as well as cost estimates for the remediation process, consideration should be given to the cost / benefit ratio in order to select the most appropriate technical and environmental point of view for a sanation scenario, while simultaneously economical and purposeful use of financial resources.

Capital investment in the reconstruction of industrial facilities with a change in their functional purpose is lower than investment in the construction of new facilities by $15-29 \%$. These indicators vary depending on the chosen function (socio-cultural life, offices, apartments). 


\section{Pandas Anastasiia}

Budget savings are due to two factors:

- in the case of reconstruction, replacement of building structures is not required; costs are mainly due to the creation of modern engineering infrastructure;

- in case of demolition of industrial objects for the sake of new construction, the investor has to bear additional costs associated with dismantling the building, as well as compensation for the removal of garbage to specialized landfills.

As the analysis shows, in the event of a full-fledged scientific restoration of objects of cultural heritage, capital investments exceed the costs of a new construction of an object of a similar size. This is due to the high demand for the quality of restoration work, the need for appropriate licenses and competencies.

Capital expenditures for restoration, taking into account the restoration of historical interiors, have specific cost indicators, can be compared with the costs of construction of objects of the «Premium» class of different functional purposes.

At the same time, we apply such an approach as objects to cultural heritage, which means conserving and minimal repair and restoration work. In this case, the initial investments can be reduced at times and be substantially distributed over time.

\section{Obstacles to the process of redevelopment industrial zone}

In addition, the city has a complex of problems associated with the implementation process of transferring industrial enterprises from the central parts of the city beyond the city territory, ensuring the necessary conditions for adaptation of enterprises in new production areas [12, p. 8].

The key issues are the lack of a state program of investor support (preferential taxation and preferential tariffs for the use of engineering infrastructure), incentive schemes for developers. Necessary development of the system of motivational levers (Table 2), Including administrative, for the interest of developers in projects redevelopment of industrial zones, the holistic development of territories.

Considering the following aspect, namely the stimulation of the withdrawal of enterprises from industrial zones in the city center to the periphery of the city of Paris, France, proposes a system of economic privileges for industrialists and entrepreneurs in the city (Figure 3): 
Table 2

\section{Examples of incentives developers in implementing projects to redevelopment industrial zones}

\begin{tabular}{|l|l|}
\hline \multicolumn{1}{|c|}{$\begin{array}{c}\text { Project name } \\
\text { (country) }\end{array}$} & \multicolumn{1}{c|}{ Motivational components } \\
\hline $\begin{array}{l}\text { Redevelopment } \\
\text { projects in New } \\
\text { Jersey and Missouri } \\
\text { (USA) }\end{array}$ & $\begin{array}{l}\text { Credit financing in the amount of up to 100\% for clearing the } \\
\text { land and preparing for new construction. Deferment of tax } \\
\text { payments to developers, and the costs of clearing the territory } \\
\text { are paid off with unpaid taxes. }\end{array}$ \\
\hline $\begin{array}{l}\text { Docklands } \\
\text { Redevelopment } \\
\text { Project, (UK) }\end{array}$ & $\begin{array}{l}\text { Favorable tax regime in the form of exemption from the tax on } \\
\text { industrial and commercial real estate, full exemption from the } \\
\text { tax on the cost of construction of new industrial enterprises in } \\
\text { the territory of the zone, as well as coverage of the municipal } \\
\text { budget costs for the organization of new production areas, their } \\
\text { advertising and provision of transport and communications. }\end{array}$ \\
\hline $\begin{array}{l}\text { HafenCity } \\
\text { Redevelopment } \\
\text { Project (Germany) }\end{array}$ & $\begin{array}{l}\text { High-quality space. Taking into account modern ecological } \\
\text { requirements and sustainable development. Innovative, high- } \\
\text { tech approach. }\end{array}$ \\
\hline
\end{tabular}

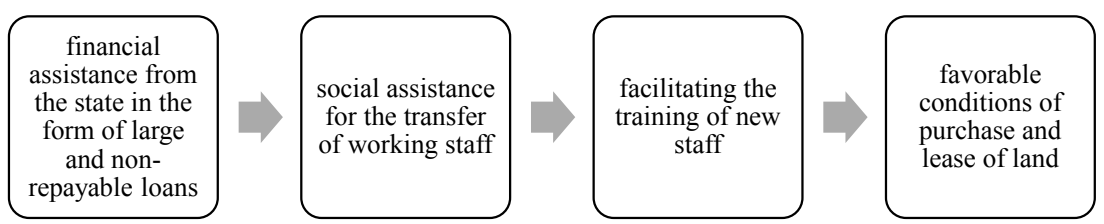

\section{Figure 3. System of economic privileges to stimulate the withdrawal of enterprises from the city center to the periphery (for example, Paris)}

On the part of the municipality, a number of restrictions were introduced:

- Prohibition of the construction of new large factories.

- Prohibition of expansion of more than $10 \%$ of existing industrial enterprises.

- Tightening control over the licensing of new industrial construction.

\section{Conclusions}

In modern urban planning processes, the need to develop new ecologicallybased methods based on cost-effectiveness in the long run. The development of complex projects for redevelopment of declining territories can serve as an instrument for «rehabilitation» of the urbanized environment in cities. 


\section{Pandas Anastasiia}

Facilitating the establishment of the institution of redevelopment of irrationally used spaces to create an ecologically-friendly urban environment is necessary, first of all, by social and ecological and economic methods. It is necessary to stimulate the rights holders of similar objects to liberate their occupied territories, in order to promote the improvement of the quality of the environment. This is possible through the following measures:

1. Introduction of a reduced rate of land tax for the owners of objects that agree to relocate.

2. Reduction of payment for connection of the developed areas to engineering communications.

3. Reclamation and restoration of disturbed as a result of industrial use of land shall be carried out at the expense of the previous and present owner of the site.

In order to evaluate the efficiency and rationality of the redevelopment project, it is necessary to consider, first of all, the economic and environmental feasibility of transferring production and other objects to other territories.

\section{References:}

1. Izmaylova K.V. (2000). Finansovyy analiz: Navch. posibnyk [Financial Analysis: Tutorial]. Kyiv: MAUP.

2. Zhurbey E.V., Zhurbey E.V., Davyborets E.N., Yeleneva E.V. (2014). Redevelopment kak perspektivnyy mekhanizm razvitiya munitsipal'nykh territoriy: zarubezhnyy i otechestvennyy opyt [Redevelopment as a promising mechanism for the development of municipal territories: foreign and domestic experience]. Oikumen. Regional studies, no. 4, pp. 90-117.

3. Dyukova O.M., Pasyada N.I. (2009). Upravleniye razvitiyem nedvizhimosti: Uchebnoye posobiye [Management of real estate development: study guide]. Saint Petersburg: Publishing house of St. Petersburg State University of Economics and Finance.

4. Matveev E.S. (1985). Promyshlennyye zony gorodov [Industrial zones of cities]. Moscow: Stroiizdat.

5. (2018). Redevelopment promyshlennykh zon ili massovaya nastroyka [Redevelopment of industrial zones or mass setting]. About-Realty.net (electronic journal). Retrieved from: http://about-realty.net/redevelopment-promyshlennyxzon-ili-massovaya-zastrojka.html

6. Koncheva E. (2019). New life of dead quarters [Novaya zhizn' mertvykh kvartalov]. 24tv.ua. Retrieved from: http://expert.ru/2011/08/2/novayazhiznmertvyih-kvartalov

7. Demidova E.V. (2013). Reabilitatsiya promyshlennykh territoriy kak chasti gorodskogo prostranstva [Rehabilitation of industrial areas as part of urban space]. Academic Bulletin UralNIIPPROEKT RAACS, no. 1, pp. 8-13. 


\section{Chapter «Economic sciences»}

8. Guriev C.N., Ovcharova E.V. (2017). Sistemnyye problemy renovatsii promyshlennykh territoriy $\mathrm{v}$ g. Voronezh [System problems of renovation of industrial areas in Voronezh]. Architectural Studies, pp. 89-97.

9. Sysoeva O.I. (2005). Rekonstruktsiya promyshlennykh obyektov: Uchebnoye posobiye [Reconstruction of industrial facilities: textbook]. Minsk: BNTU.

10. Golovanov E.B., Kiseleva V.A. (2013). Razvitiye redevelopmenta kak napravleniya po preobrazovaniyu gorodskikh territoriy [Development of redevelopment as a direction for the transformation of urban areas]. Bulletin of SUSU. Series: «Economics and Management», no. 3 (7), pp. 12-16.

11. Blaginyh E.A. (2015). Aktualizatsiya napravleniy nauchnoissledovatel'skikh rabot po sovershenstvovaniyu arkhitekturno gradostroitel'nykh protsessov v Kemerovskoy oblasti [Actualization of areas of research to improve the architectural and urban planning processes in the Kemerovo region]. Bulletin of SibGIU, no. 1 (11), pp. 59-62.

12. Polshchikova N.V., Safonov E.V. (2017). Renovatsiya i rekontseptsiya promyshlennykh zdaniy [Renovation and reconception of industrial buildings]. $O G A S A$, pp. 1-8. 